\title{
Szó- és jelentéstörténeti vizsgálatok A romániai magyar nyelvjárások atlasza alapján*
}

1. Egy nyelvatlasz munkálatai a szerkesztőktől nagy odafigyelést, türelmet és sok-sok időt kívánnak. A feladat jelentős része meglehetősen monoton, ismétlődő munkafolyamatok egymást követő sorát jelenti. A végeredmény azonban sok mindenért kárpótol. Komoly előnyt élvezünk más kutatókkal szemben, hiszen a térképlapokat sokkal többször látjuk, az egyes kutatópontok nyelvi jellegzetességeit jól ismerjük, a kérdőív egymást követő adatainak összefüggéseire is nagyobb rálátásunk van. Ez a lehetőség azonban kötelez is bennünket. A mi feladatunk nem ért véget a szerkesztéssel; arra is oda kell figyelnünk, hogy minél szélesebb körben ismertté váljanak ennek a hatalmas gyüjteménynek a nyelvészeti értékei, minél több kutató kedvet kapjon a térképlapok böngészéséhez, elemzéséhez. Ezért is örömteli a mai alkalom, amikor szélesebb körben is bemutathatjuk, milyen változatos kutatási témákat kínál A romániai nyelvjárások atlasza.

2. A szóföldrajzi adatok hangtani, morfematikai, lexikai vizsgálatához bőséges szakirodalom segíti az érdeklődő munkáját. A jelentéstani kérdésekkel viszont lényegesen kevesebb munka foglalkozik. Ennek okaira JUHÁSZ DEZső világított rá (JUHÁSZ 2000: 134-135): nehéz feltárni a szócsoportok jelentésstruktúráját a hagyományos nyelvatlaszos gyüjtési technikával, a gyüjtés maga nagy felkészültséget kíván a kutatótól, és kérdéses, hogy milyen eredményre vezetne a munka, vagyis mutatkozik-e érdemleges táji különbség a jelentéstani adatokban. Nem hagyható figyelmen kívül a kutatói mentalitás sem. A dialektológusok eddig kevéssé vállalkoztak arra, hogy a szemantika legújabb eredményeiben elmélyedve az új módszereket szóföldrajzi vizsgálatoknál is alkalmazzák, a szemantikusok pedig a köznyelven kísérletezik ki elméleteiket.

A két tudományág eredményeinek szembesítése új kérdéseket és válaszokat vethet fel. Tanulmányomban e kevéssé ismert kapcsolatok közül a szóföldrajz és a jelentésmezők viszonyával foglalkozom, ennek is különösen elhanyagolt területével, a melléknevek jelentéstani vizsgálatával.

3. Az eddigi nyelvföldrajzi publikációkból jól látható, hogy nemcsak az egyes nyelvek standardjainak összevetésekor figyelhető meg egy adott jelentésmező eltérö tagolása, hanem az adott nyelv nyelvjárásain belül is. A dialektológiai szakirodalom ezt a jelenséget az egyes fogalmak tagoltsága, illetve az összegyüjtött szóanyag rétegződése szempontjából tárgyalja (MURÁDIN 1969, 1975, 1976, 1978; IMRE 1981, 1985, 1987; TERBE 1999; CS. NAGY 2003, illetve a nyelvföldrajz és a jelentéstan kapcsolatáról JUHÁsZ 2000, 2002, 2003).

* Az Egy elkészült és egy készülő magyar nyelvatlasz - kutatási tapasztalatok és perspektívák címü konferencián 2011. november 23-án elhangzott előadás szerkesztett, bővített változata.

Magyar Nyelv 112. 2016: 140-151. DOI: 10.18349/MagyarNyelv.2016.2.140 
A sokrétü, újdonságokat is tartalmazó tanulmányok ellenére az olvasónak mégis hiányérzete van. A leíró jellegü vizsgálatok nem adnak arra a kérdésre választ, hogy az egyes szemantikai mezőkhöz tartozó lexikai egységek (itt, a szóföldrajzi anyag esetében többnyire tautonimák) milyen alapon kötődnek egymáshoz. Milyen közös jelentéskomponensek mutathatók ki, van-e a közös vagy éppen eltérő jelentésmozzanatoknak szóföldrajzi vonatkozása? Egyáltalán: hogyan bonthatók fel az összegyüjtött tautonimák szemantikai jegyekre?

Az egyoldalú jelentésmező-elemzések másik oka a témaválasztásban rejlik. A korábbi és a mai jelentéstani cikkek leginkább növények, állatok, eszközök megnevezéseivel foglalkoznak.

4. KIEFER szerint (2000: 65) a rokon értelmü, azonos szemantikai mezőhöz tartozó szavak közötti kapcsolat, illetve a jelentésük közötti különbség szemantikai jegyekkel, komponensekkel fejezhető ki. Azonban a jelentésfelbontásnak is vannak korlátai. A mintaelemzések bebizonyították (KIEFER 2000: 66-68), hogy éppen az állatok, növények, tárgyak nevének jelentésfelbontásánál nem alkalmazható a komponenses elemzés; ezek jelentése nem írható le adekvát módon szemantikai jegyekkel. A sütőtök, sütni való tök, úritök, bécsitök, pécitök, patyolattök stb. elnevezések nem bonthatók jelentés-összetevőkre, az egyes megkülönböztető jegyek csak az adott szemantikai mezőben, a tautonimák jelentésének megkülönböztetésére, illetve a közös jelentésének meghatározásához használhatók.

Az igék vizsgálata viszont több sikerrel kecsegtet, ugyanis azok jelentése valamilyen mélységig mindig felbontható, amint az például az 'ellik' jelentésü szavak esetében is tapasztalható (MURÁDIN 1976; IMRE 1985; JUHÁSZ 2003).

5. A mellékneveket vizsgálva nemigen hagyatkozhattam korábbi tapasztalatokra, ennek a szófajnak dialektológiai szemantikai szakirodalma igencsak hiányos. Ezért is érdekelt, milyen jellegü kérdések merülhetnek fel egy melléknév táji tagolódásában, milyen a szemantikai variabilitása.

A romániai nyelvatlasz gazdag anyaga lehetővé tette, hogy ne csak magában egy-egy szót vizsgáljak, hanem részrendszereket, illetve az adott szó részrendszerbeli viselkedését is feltárjam.

$\mathrm{Az}$ 5. kötetben egy ilyen összefüggő kérdéssorozat keltette fel a figyelmemet, melynek nyelvtörténeti vonatkozásaival már korábban is foglalkoztam (TERBE 2003, 2006).

Az 1280. és 1305. sorszám közé eső, egymást követő címszavak a másodlagos emberi tulajdonságok fogalmi körének szóföldrajzi realizációját mutatják be. A huszonhárom térképlapból álló sorozat tagjai között jelentős eltérés mutatkozik a megnevezendő fogalom lexikai tagoltsága tekintetében. A válogatós, gyáva, bátor, kétszínü, irigy, fösvény, részeg, részeges, habari ('gyors beszédü <ember>'), pletykás, büszke és a serény esetében meglehetősen egységes képet mutat a térkép, míg a falánk, kákabelü, nyalakodó, izgága, haragos, makacs, kényes, kacérkodó, felületes, szófukar és a csúfszájú címszavaknál pedig igen erős variabilitást tapasztalhatunk. Ez a nagyfokú változatosság érdekesnek látszik. 
6. Úgy tünik, hogy az egységesebb képet mutató címszavak esetében a beszélőközösség számára lényeges jelenségekről van szó, fogalmi kódolásuk elfogadott, ismert. A másik csoport elemei is fontos fogalmakra vonatkoznak, de lexikalizálásuk mégsem ad általánosan elfogadott, önálló szót a beszélők számára.

A térképlapok címszava általában a fogalom köznyelvi megfelelője, ami természetesen nem jelenti a lexéma tájnyelvi elsőségét, kizárólagosságát. Valójában a hozzájuk kapcsolódó kérdés az irányadó, a fogalmat a címszó gyakran nem is határozza meg egyértelmüen (DEME-IMRE szerk. 1975: 101-103). A vizsgált térképlapok esetében például a kacérkodó címszó 1 , a szófukar 4, a felületes 6 , a falánk 7, az izgága 10, a haragos 12, a kákabelü 15 kutatóponton jelent meg a 136-ból.

Az elmondottakból következik, hogy különösen nagy figyelmet kell fordítani a kérdések egzakt megfogalmazására. A ,Milyen a...” kezdetü kérdéseket megvizsgálva és a kapott adatokat összevetve kiderül, hogy nem minden esetben sikerült pontosan körülhatárolni a kérdéses viselkedést, tulajdonságot, illetve a válaszadó nem mindig azt értette a kérdésen, mint amire a kutató számított. Így például a kákabélü esetében [Milyen az a gyerek, aki nagyon keveset eszik?] a válaszok egy része a kicsi étkűségre, másik fele a soványságra vonatkozott. A haragos-nál [Milyen ember az, aki hirtelen megharagszik, felfortyan?] a kapott válaszok a haragvás okára is utalnak (sértödös, durcás, veszekedös, bosszús stb.). A kényes kérdése pedig már megfogalmazásában is [Milyen az a gyermek, aki mindig kedvetlen és minden semmiségért siránkozik?] előrevetíti a kétirányú válaszokat. A pontatlanul megfogalmazott kérdések is hozzájárulnak a tagoltabb kép kialakulásához.

A gyüjtéstechnika vélt vagy valós hiányosságai mellett lényegesen nagyobb súlyúak a fogalomkörök táji lexikai tagolódásából adódó mennyiségi különbségek. A területi tagoltságot befolyásolhatja a fogalomnak a megnevezési rendszerben betöltött helye. Mint tudjuk, az alapfogalmak tagolatlanok, viszont a részrendszerek elnevezései már nagyobb variabilitást mutatnak. A másodlagos emberi tulajdonságok közül azoknál, amelyek egyértelmúen meghatározható viselkedéseket jelölnek, minimális tagoltságot tapasztalunk. Úgy tünik, az emberi tulajdonságok mezőösszefüggésein belül a hierarchia magasabb fokán állnak. Ez nyilván összefügg azzal az általános alapelvvel, amely szerint a mindennapi életünkben szerepet játszó fogalmak megnevezési rendszerei kevéssé tagoltak - jelen esetben a gyávaság, bátorság, irigység stb. általánosabb, könnyebben meghatározható tulajdonságok, egyértelmúbb viselkedési formák, az emberi közösségekben mindig is előfordultak. Ehhez képest a falánk, kákabélü, nyalakodó, a makacs, haragos, izgága, vagy a kacérkodó, szófukar, csúfszájú tulajdonságok már nem ilyen általános érvényúek; speciális, alkalmi viselkedési formák. A hétköznapi életben kevéssé fontos vagy kevéssé ismert fogalmakra nem mindig foglalódott le önálló szó, esetlegesebb a szóhasználat vagy a meglévő tautonimák nem általános érvényüek.

A szóstatisztika is ezt támasztja alá (a táblázatban: összadat száma; ebből hapax; a megnyilatkozó kutatópontok számához képest a hapaxok aránya; nincs adat): 


\section{1. táblázat}

A kutatópontok megoszlása

\begin{tabular}{|c|c|c|c|c|}
\hline Címszó & Adat & Hapax & $\%$ & $\varnothing$ adat \\
\hline kényes & 56 & 24 & 19 & 7 \\
\hline kákabelü & 52 & 38 & 29 & 5 \\
\hline haragos & 46 & 34 & 26 & 4 \\
\hline csúfszájú & 41 & 24 & 19 & 7 \\
\hline kacérkodó & 38 & 25 & 19 & 4 \\
\hline szófukar & 36 & 24 & 18 & 3 \\
\hline felületes & 35 & 17 & 14 & 17 \\
\hline izgága & 29 & 15 & 11 & 0 \\
\hline makacs & 26 & 19 & 14 & 2 \\
\hline nyalakodó & 26 & 15 & 11 & 0 \\
\hline falánk & 25 & 14 & 10 & 1 \\
\hline
\end{tabular}

A kutatópontok szerinti megoszlásból is érdekes következtetéseket lehet levonni. A 136 településböl mindössze 15 olyan hely akadt, ahol mindig közöltek adatot, és ezek nem egyedi szóhasználatot tükröztek. Ahonnan a legtöbbször nem kaptak választ: Misztótfalu (B: 5) 5, Székelyvarság (M: 7) 3, továbbá 2-2 alkalommal Gencs (B: 3), Miriszló (K: 4), Szabéd (L: 3) és Székelyzsombor (T: 6).

A legtöbb hapax a csángóföldi Szabófalváról (H: 1) érkezett, a 11 kérdésből 9 esetében. És ugyancsak magas számot találunk a következő helyeken is: a mezőségi Ördöngösfüzes (F: 6) 7, a Temes melletti Szapáryfalva (P: 1) 6, a szintén mezőségi Baca (F: 1) és Magyarszovát (L: 1), a székelyföldi Apáca (T: 14), valamint a csángó Bogdánfalva (N: 1) és Diószeg (U: 8) településeken, 5-5 alkalommal. A kirívóan magas gyakoriság adódhat természetesen az adatközlők egyéni adottságaiból, ismereteiből is, azonban tendenciaszerüen megállapítható, hogy a Szilágyságban, a Mezőségen, Erdély középső részein, valamint a csángó területen a szóban forgó 11 fogalomra igen gyakran egyszeri szóhasználattal felelnek. Ez különösen az elszigetelt helyzetü településekre jellemző.

7. Az általános szemantikai okok mellett azonban a magyarázatot magukban a fogalmakban kell keresnünk. Azt, hogy a kérdésekre érkező tautonimák, szinonimák milyen mezőösszefüggésben állnak, milyen szemantikai érintkezés rendeli őket egy fogalomkörhöz, csak mikrofilológiai vizsgálattal lehet egyértelmüen meghatározni. 


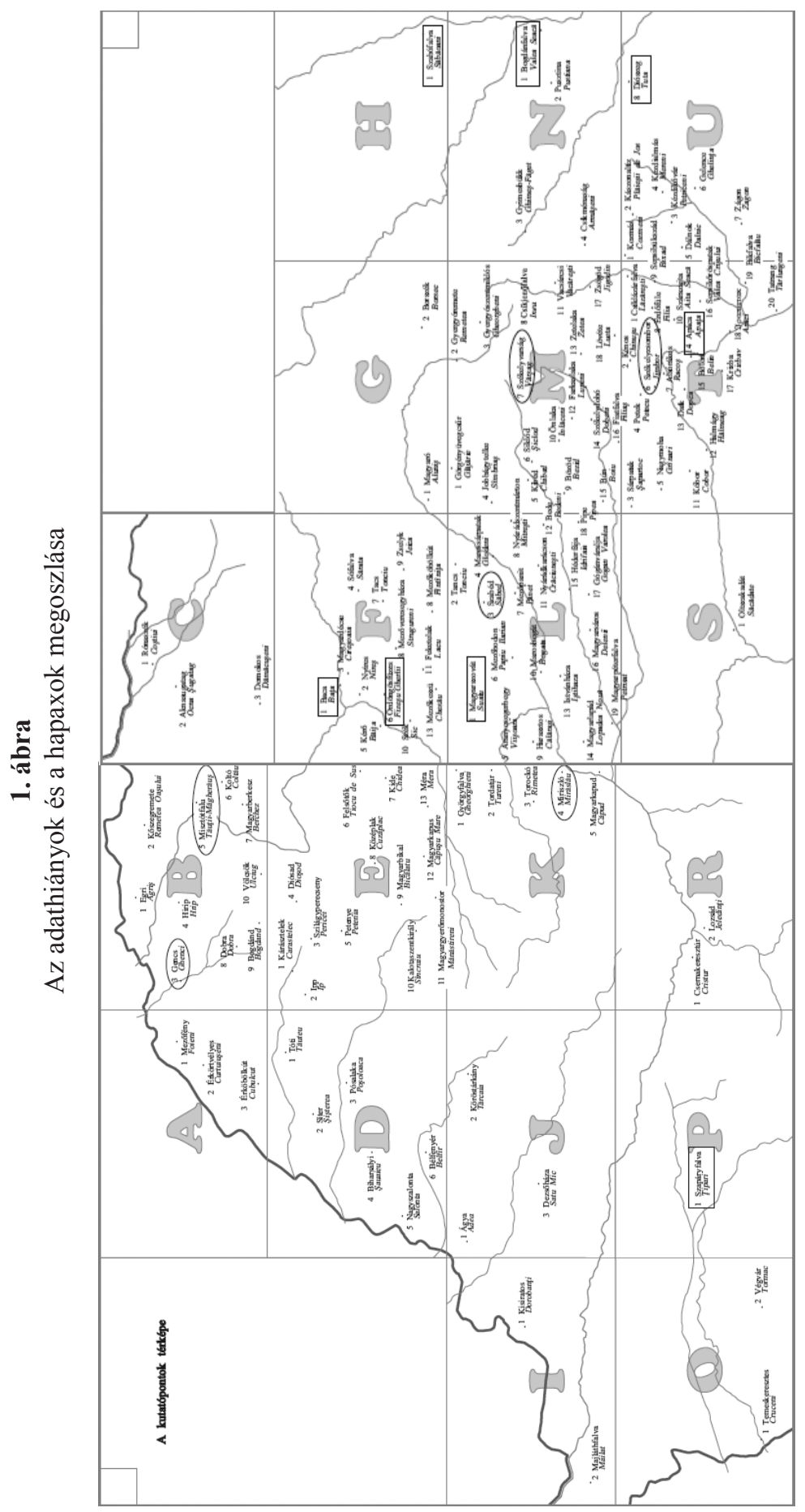




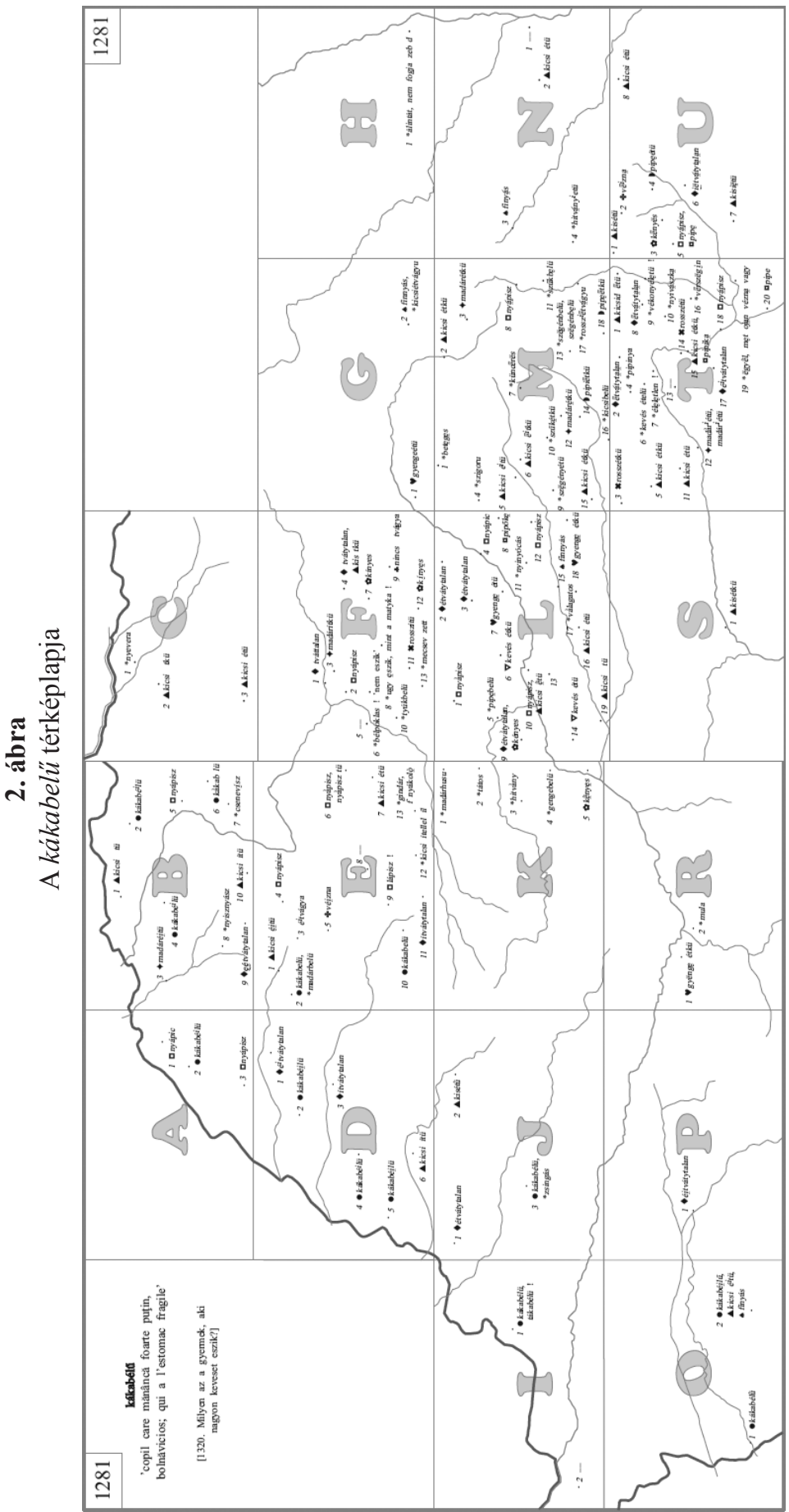


A táblázatban szereplő címszavak közül a kákabelü (1281.) több adatában is kiemelkedik a többi közül: igen sok, 52-féle kifejezés érkezett a kérdésre, és a legtöbb hapax is itt fordul elő. A rendkívül tagolt kép és a sok egyedi megnevezés arra utalhat, hogy a kérdésre nincs egységes megnevezés, illetve a „Milyen az a gyermek, aki nagyon keveset eszik?" meghatározás különböző asszociációkat kelt az adatközlökben.

Az adatokat - mint már korábban szó esett erről - két nagyobb csoportra lehet osztani: az egyik a külső fizikai megjelenésre, vagyis a soványságra vonatkozó kifejezések, a másik a kis étküségre utalók:

\section{2. táblázat}

Az adatok szemantikai csoportosítása

\begin{tabular}{|c|c|}
\hline 'vékony' & 'kicsi étkü' \\
\hline & kákabelü, kicsi étü, madárétü, étvágytalan, \\
nyápic, nyápisz, vézna, *cse- & madárbelü, kisétkü, kevés étkü, rosszétkü, \\
nevész, *nyisznyász, lápisz!, & pipiétkü, madárétkü, gyenge étü, gyenge \\
*gindár, *zsingás, *madár- $_{\text {hútkú, nincs étvágya, pipe, pipika, pipöke, }}^{\text {hú, *hitvány, *vérszegény, }}$ & finnyás, kényes, *gyengebelü, *kicsi étellel \\
*nyevera, *nyivászka, *szi- & él, *tyúkbelü, *pipebelü, *kicsibelü, *sze- \\
gorú, *mecsevezett, *egyél, & génybelü, *szükbelü, *madárbelü, *szükétkü, \\
mert olyan vézna vagy, *bete- & *szegényétkü, *hitványétü, *rosszétvágyú, \\
ges, *nyinyócás & *kicsiétvágyú, *kevés ételü, *úgy eszik, mint \\
& a macska, *válogatós, *pipinya \\
\hline
\end{tabular}

Az adatok közül néhányat nem lehet a fenti csoportokba besorolni: *bélpoklos 'nem eszik'; *mula, *tátos 'bamba, mamlasz'; valamint az ismeretlen jelentésủ *künceres, *fényákoló adatokat.

8. Magát a címszóként felvett kifejezést is érdemes közelebbről megvizsgálni.

A kákabelü a CzUCZOR-FOGARASI-féle szótár (CzF.) szerint: „Kinek gyönge béle van, mely emészteni nem képes, melynek hamar megárt minden, mely erötlen, mint a káka. Kényes, finnyás."

Az értelmező szótár (ÉrtSz.) is hasonló meghatározást ad: 'gyenge gyomrú, kényes, beteges személy, föleg férfi; finnyás, ételekben válogatós, kis étkü'.

A SzINNYEI-féle tájszótár (MTsz.) szerint 'gyenge gyomrú, kényes gyomrú, keveset evő, ételben válogatós, finnyás személy'. Sajnos az ÚMTsz. az EKsz. ${ }^{2}$, a TESz. és az EWUng. sem veszi fel címszóként. Ami az elterjedését illeti, a térképlapon jól látható, a szó nem ismert a történelmi Erdélyben. 


\section{3. ábra}

A kákabelü elterjedése

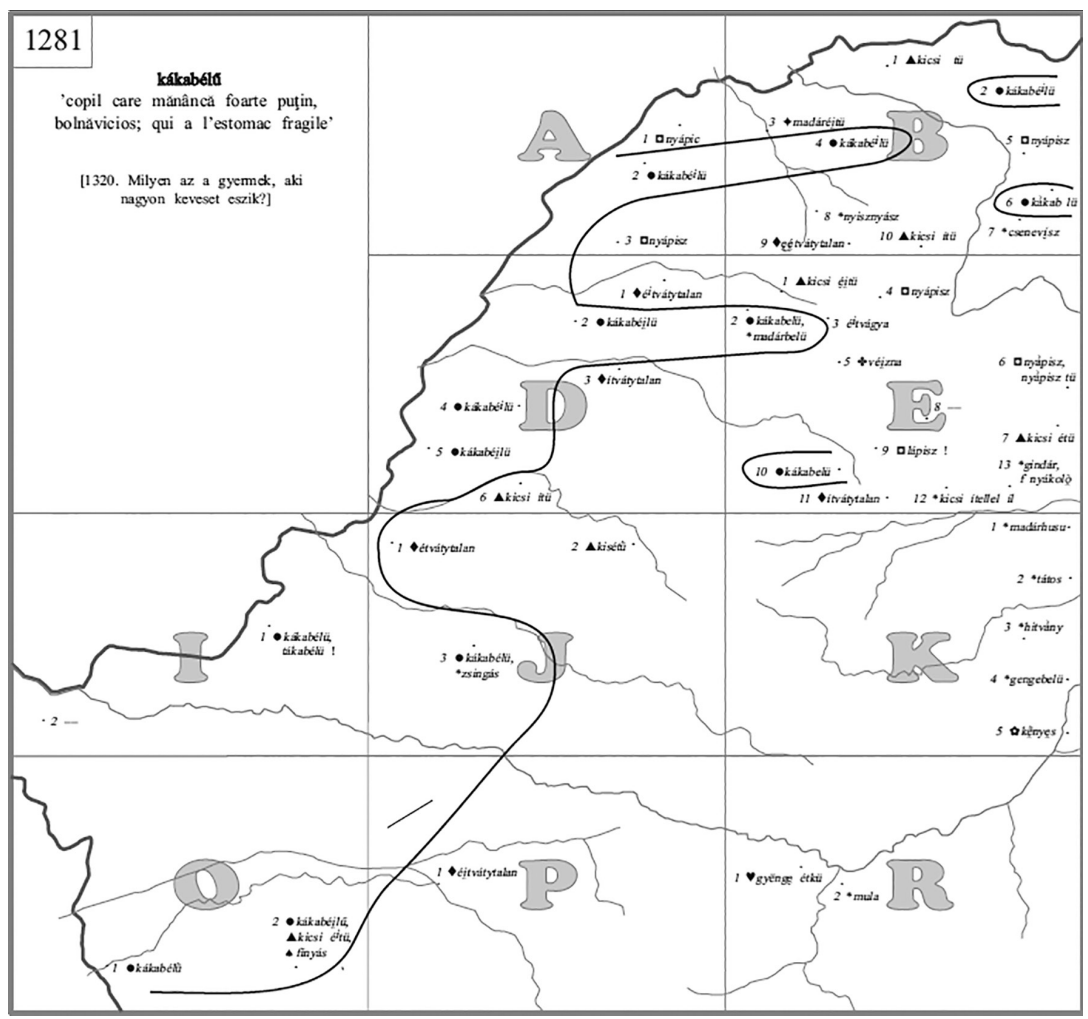

9. Ezek után joggal vetődik fel: mi van helyette?

Mielőtt áttekintenénk az alternatívákat, érdemes egy kicsit elgondolkodni azon, hogy a fogalmi kódolás miként zajlik. Ez ugyanis elárulhatja, hogy a beszélöközösség hogyan viszonyul az adott fogalomhoz.

Egy kérdés megválaszolása nem csupán nyelvi feladat. Még a témakörök szerint rendezett kérdések is gondot okozhatnak a beszélőnek. A kérdezz-felelek gyüjtési szituáció az ilyen helyzethez nem szokott, gyakran idős, iskolázatlan embert feszélyezi, mindenképpen szeretne megfelelni az elvárásoknak. Az olyan típusú kérdéseknél, amelyek szorosan kapcsolódnak a hétköznapi élethez, annak tárgyaihoz, jelenségeihez, az adatközlő otthonosan mozog: a pontosan körülírt dolgok megnevezését vagy tudja, vagy nem.

Lényegesen nehezebb az adatközlő helyzete, amikor már a kérdés sem teljesen egyértelmủ számára. Bizonytalansága többek közt abból is eredhet, hogy a gyüjtő egy olyan fogalomra kérdez, ami az adott régióban nem ismert, vagy a beszélö érdeklődésétől távol áll, vagy olyan értékítéletet kell hoznia a válaszadás előtt, amely nyelven kívüli tényezőktől függ. Ez utóbbi esethez sorolható a vizsgált kérdés is. 
Az adatközlőnek mérlegelnie kell, hogy számára a 'vékony' és a 'kicsi étkü' ebben a szövegkontextusban szinonima-e, a valóság egyetlen mozzanatát idézik-e fel, és létezik-e olyan kifejezés a szótárában, amely alkalmas ennek jelölésére. Ha pedig a kérdést hallva a két fogalomhoz más-más szituáció kapcsolódik, mentális lexikonában is vagy az egyik, vagy a másik dologhoz keres adekvát nyelvi kifejezőeszközt.

10. Mindezeket mérlegelve, nézzük meg, milyen válaszok születtek.

A vékony testalkatra utaló kifejezések általában hangfestő eredetủek: nyápic, nyápisz, vézna, *csenevész, *nyisznyász stb. A vékonyság mellett megjelenik a betegség fogalma, hiszen a beteg ember gyakran sovány is. Ezt a jelentésárnyalatot fejezi ki a vérszegény és a beteges adat. Néhány nyelvtörténeti, jelentéstörténeti érdekességet is megfigyelhetünk. Ilyen például a zsingás és a gindár, amelyek a román $d z s i n g a ́ s-$ ból származnak, és a magyar zsengés-ből eredeztethetők: visszakölcsönzéssel kerültek a magyarba. Az adatok a belső-mezőségi Méráról és Köröstárkányból valók.

A hitvány szót a mai köznyelvben a 'silány', illetve az elvontabb 'gyarló, esendö' jelentésben használjuk. Eredeti jelentései közül a 'sovány' a legkorábbi, 1171-böl. Az adatot Torockón gyüjtötték.

A szigorú mai jelentése a nyelvújítás korából származik, eredetileg 'nyomorúságos, szegényes, szűkölködő, fejletlen, satnya, csenevész, sovány, vézna, szikár’ jelentésekben használták. A székelyföldi Jobbágytelkéről származik az adat.

A szócsoport másik fele igen sokszínű: a kifejezések zöme jelzős szerkezet, a kis, kicsi, kevés, gyenge, szegény, szük, rossz jelzőket tartalmazza az étkü, étü, étvágyú szavak mellett. Sajátos csoportot alkotnak azok a kifejezések, amelyek egy-egy állathoz hasonlítják a rossz étvágyú gyereket. Leginkább a 'csirke, tyúk' jelentésü pipe fordul elő, de megtalálható az általánosabb érvényü madár megnevezés is. Az úgy eszik, mint a macska kifejezés nem csupán a kevés ételre, de válogatós, finnyás, kényes gyerekre is utalhat.

A szintaktikai mező tagoltsága a nyelvföldrajzi realizációban is megmutatkozik. Az általánosan elfogadott megnevezés hiányában a szóföldrajzi elrendeződés nagyfokú tarkaságot és talán bizonytalanságot is tükröz. Különösen feltünő a sok hapax (29 esetben). A kérdésben felvázolt fogalomkör általában kódolatlan a nyelvterületen, a köznyelvi megnevezés alig ismert, és az adatok sokfélesége azt valószínüsíti, hogy korábban sem volt egységes elnevezése.

A már-már kaotikusnak látszó elrendeződésből azonban néhány tájnyelvi jellegzetesség is kiolvasható. Például a pipeétkü és változatai elsősorban Székelyföldön ismertek, vagy a köznyelvben jól ismert étvágytalan kifejezés az erdélyi nyelvjárásokban csak szórványosan fordul elő (TESz., EWUng., MÁRTON-PÉNTEK-VÖÖ 1977).

11. Tanulmányomban igyekeztem felvázolni, milyen érintkezési pontjai lehetnek a nyelvföldrajzi és a jelentéstani vizsgálatoknak. A nyelvföldrajzi adatok lexikai, szemantikai vizsgálata nemcsak a dialektológia, hanem más nyelvészeti és társadalomtudományi diszciplínák számára is szolgálhat tanulsággal. Az eredmények értékét különösen növeli, ha olyan területen sikerül új adatokra bukkanni, amit eddig kevéssé ismertünk. Az efféle vizsgálatokhoz pedig a nyelvatlasz kiapadhatatlan forrás. 
Kulcsszók: dialektológia, nyelvföldrajz, erdélyi és moldvai magyar nyelvjárások, szójelentéstan, részrendszerek.

\section{Hivatkozott irodalom}

CzF. $=$ CZUCZOR GERGELY - FOGARASI JÁNOS, A magyar nyelv szótára 1-6. Emich Gusztáv / Athenaeum, Pest / Budapest.

DEME LÁSZLÓ - IMRE SAMU szerk. 1975. A magyar nyelvjárások atlaszának elméletimódszertani kérdései. Akadémiai Kiadó, Budapest.

ÉKsz. ${ }^{2}=$ Magyar értelmező kéziszótár. Főszerk. PUSZTAI FERENC. 2., átdolgozott kiadás. Akadémiai Kiadó, Budapest, 2003.

ÉrtSz. = A magyar nyelv értelmezö szótára 1-7. Főszerk. BÁRCZI GÉZA - ORSZÁGH LÁSZló. Akadémiai Kiadó, Budapest, 1959-1962.

EWUng. = Etymologisches Wörterbuch des Ungarischen 1-2. Hrsg. BENKÖ, LORÁND. Akadémiai Kiadó, Budapest, 1993-1995.

IMRE SAMU 1981. Egy fogalomkör nyelvjárási megnevezéseinek típusai. Magyar Nyelv 77: $1-20$.

IMRE SAMU 1985. Egy igecsoport néhány szóföldrajzi jellemzője. Magyar Nyelv 81: 87-93. IMRE SAMU 1987. Nyelvjárási szókészletünk néhány szerkezeti kérdése a magyar nyelvatlasz anyaga alapján. Értekezések[,] emlékezések. Akadémiai Kiadó, Budapest.

JuHÁSz DEZSÖ 2000. Szójelentéstan és nyelvföldrajz. In: GECSÖ TAMÁS szerk., Lexikális jelentés, aktuális jelentés. Segédkönyvek a nyelvészet tanulmányozásához 4. Tinta Kiadó, Budapest. 134-141.

JuHÁSz DEZsŐ 2002. A jelentéstani mikrorendszerek térbeliségének kérdéséhez. In: GECSÖ TAMÁs szerk., Kontrasztív szemantikai kutatások. Segédkönyvek a nyelvészet tanulmányozásához 11. Tinta Kiadó, Budapest. 169-181.

JuHÁSZ DEZSÖ 2003. Egy fejezet a történeti jelentésföldrajzból. In: BÜKY LÁsZLÓ - FORGÁCS TAMÁs szerk., A magyar nyelvtörténeti kutatások legújabb eredményei III. Magyar és finnugor jelentéstörténet. SZTE Magyar Nyelvészeti Tanszék, Szeged. $107-117$.

KÁROLY SÁNDOR 1970. Általános és magyar jelentéstan. Akadémiai Kiadó, Budapest.

KIEFER FERENC 2000. Jelentéselmélet. Corvina Kiadó, Budapest.

KISS JENŐ 1995. Társadalom és nyelvhasználat. Nemzeti Tankönyvkiadó, Budapest.

KISS JENŐ 1999. A beszédhelyzet mint kutatási szempont a dialektológiában. Magyar Nyelvjárások 36: 285-292.

KISS JENÖ szerk. 2001. Magyar dialektológia. Osiris, Budapest.

LENGYEL KLÁRA 2000. A melléknév. In: KesZler BORBÁLA szerk., Magyar grammatika. Nemzeti Tankönyvkiadó, Budapest. 142-152.

MÁRTON GYULA - PÉNTEK JÁNOS - VÖÖ ISTVÁN 1977. A magyar nyelvjárások román kölcsönszavai. Kriterion, Bukarest.

MTsz. = SzINNYEI JÓZSEF, Magyar tájszótár 1-2. Hornyánszky, Budapest, 1893-1901.

MURÁDIN LÁszLÓ 1969. A jelentésmező tagolása és a nyelvjárási izoglosszák. Nyelv és Irodalomtudományi Közlemények 13: 301-305.

MURÁDIN LÁSZLÓ 1975. Háziállatok tartására szolgáló épületek neveinek belső és területi összefüggéseihez. Nyelv- és Irodalomtudományi Közlemények 19: 133-141. 
MURÁDIN LÁSZLÓ 1976. Az ellik és rokon értelmű társainak jelentésköre. Nyelv-és Irodalomtudományi Közlemények 20: 19-30.

MURÁDIN LÁSZLÓ 1978. A 'tulajdont őrző személy' jelentésmező jelölése és tagolása a romániai magyar nyelvjárásokban. Nyelv-és Irodalomtudományi Közlemények 22: $159-174$.

Cs. NAGY LAJos 2003. Lexikológiai vizsgálatok a Medvesalján. Notitia historicoethnologica 4. Forum Kisebbségkutató Intézet - Lilium Aurum Könyvkiadó, Komárom-Dunaszerdahely.

RMNyA. 5. = A romániai magyar nyelvjárások atlasza 5. Gyüjtötte és a kéziratot összeállította MurÁdin LÁSZLÓ. Szerk. JuHÁSz DEZSŐ. Magyar Nyelvtudományi Társaság Pharmapress Kiadó, Budapest, 1999.

TERBE ERIKA 1999. Örvény. Szemantikai és szóföldrajzi vizsgálódás. In: KUGLER NóRA LENGYEL KLÁRA szerk., Ember és nyelv. Tanulmánykötet Keszler Borbála tiszteletére. ELTE BTK Mai Magyar Nyelvi Tanszék, Budapest. 314-321.

TERBE ERIKA 2003. Szemantikai vizsgálat nyelvföldrajzi és történeti tanulságokkal. In: BÜKY LÁSZLÓ - FORGÁCS TAMÁs szerk., A magyar nyelvtörténeti kutatások legújabb eredményei III. Magyar és finnugor jelentéstörténet. SZTE Magyar Nyelvészeti Tanszék, Szeged. 191-196.

TERBE ERIKA 2006. Kényes. Szemantikai vizsgálat nyelvföldrajzi tanulságokkal. In: MÁRTONFI ATTILA - PAPP KornÉliA - Slíz MARIANN szerk., 101 irás Pusztai Ferenc tiszteletére. Argumentum, Budapest. 215-224.

TESz. = A magyar nyelv történeti-etimológiai szótára 1-3. Főszerk. BENKÖ LORÁND. Akadémiai Kiadó, Budapest, 1967-1976.

\section{Studies in word history and historical semantics based on The Atlas of Hungarian Dialects in Romania}

Dialectologists seldom undertake the task of delving into the most recent results of semantics and of applying the newest methods in their investigations of word geography; semanticians, on the other hand, usually base their theories on standard languages. The geographic distribution of the behaviour of adjectives is an area of which particularly little is known. However, diversity in the articulation of a given semantic field is not only observable when different standard languages are compared: such diversity can also be seen in comparing various dialects of the same language. The rich material comprised in The Atlas of Hungarian Dialects in Romania has made it possible to study various subsystems and the behaviour of a given word across those subsystems. In the present paper the conceptual area of secondary human properties and, in particular, the data of the map of kákabelü 'poor trencherman, thin (person) etc.' (Map 1281) are thoroughly analysed.

Keywords: dialectology, linguistic geography, Hungarian dialects in Romania, word semantics, subsystems.

TERBE ERIKA

Eötvös Loránd Tudományegyetem 